\title{
Validation study of risk prediction models for female relatives of Australian women with breast cancer
}

\author{
R MacInnis ${ }^{1,2^{*}}$, G Dite ${ }^{1}$, A Bickerstaffe ${ }^{1}$, J Dowty ${ }^{1}$, K Aujard $^{1}$, C Apicella ${ }^{1}$, K Phillips $^{1,3}$, P Weideman ${ }^{3}$, J Hopper ${ }^{1}$ \\ From Familial Aspects of Cancer 2011 Research and Practice: A combined meeting of kConFab, Australian \\ Breast Cancer Family Study, Australian Colorectal Cancer Family Study, Australian Ovarian Cancer Study, \\ Family Cancer Clinics of Australia and New Zealand and kConFab \\ Kingscliff, Australia. 23-26 August 2011
}

Risk prediction algorithms are an important tool for identifying individuals at high risk of developing the disease who can then be offered individually tailored clinical management. Several algorithms that predict the probability of breast cancer incidence are currently used in clinical practice. It is uncertain, though, as to which of the breast cancer risk prediction models performs best for female relatives of Australian women with breast cancer.

We evaluated the performance of the risk prediction algorithms BOADICEA, BRCAPRO and the Gail model using 879 families of ABCFS case probands, half of whom were diagnosed before age 40 years and the remainder before age 60 years. Cumulative breast cancer risks over 10 years of follow-up were calculated for 2000 unaffected female relatives.

A total of 93 incident breast cancers were reported. The ratios $(95 \% \mathrm{CI})$ of expected to observed number of breast cancers were 0.69 (0.56-0.84) using BOADICEA, 0.62 (0.51-0.77) using BRCAPRO, and 0.89 (0.73-1.09) using the Gail model. Tests for discrimination (ROC curve) were BOADICEA $=0.61, \mathrm{BRCAPRO}=0.64$, and the Gail model $=0.65$.

Similar analyses using other models, including the Tyrer-Cuzick (IBIS) and Claus models, will also be presented.

\section{Author details}

${ }^{1}$ Centre for MEGA Epidemiology, University of Melbourne, Australia. ${ }^{2}$ Cancer Epidemiology Centre, The Cancer Council Victoria, Australia. ${ }^{3}$ Division of Haematology \& Medical Oncology, Peter MacCallum Cancer Centre, Australia.

${ }^{1}$ Centre for MEGA Epidemiology, University of Melbourne, Australia Full list of author information is available at the end of the article
Published: 12 April 2012

doi:10.1186/1897-4287-10-S2-A66

Cite this article as: Maclnnis et al:: Validation study of risk prediction models for female relatives of Australian women with breast cancer. Hereditary Cancer in Clinical Practice 2012 10(Suppl 2):A66.
Submit your next manuscript to BioMed Central and take full advantage of:

- Convenient online submission

- Thorough peer review

- No space constraints or color figure charges

- Immediate publication on acceptance

- Inclusion in PubMed, CAS, Scopus and Google Scholar

- Research which is freely available for redistribution

Submit your manuscript at www.biomedcentral.com/submit
() Biomed Central
C Biomed Central

(c) 2012 MacInnis et al; licensee BioMed Central Ltd. This is an Open Access article distributed under the terms of the Creative Commons Attribution License (http://creativecommons.org/licenses/by/2.0), which permits unrestricted use, distribution, and reproduction in any medium, provided the original work is properly cited. 